\title{
The Process of Establishing Family Support for Rehabilitated Adolescent Drug Abusers at Bangli Mental Hospital
}

\author{
Master Degree of Medical Study Program \\ Postgraduate Programs-Udayana University \\ Denpasar \\ sariyani27@ymail.com \\ Midwifery Diploma \\ STIKES Advaita \\ Tabanan \\ Postgraduate Programs-Udayana University \\ Denpasar \\ Postgraduate Programs-Udayana University \\ Denpasar
}

Made Dewi Sariyani ${ }^{1}$, Kadek Sri Ariyanti² ${ }^{2}$ Dyah Pradnyaparamita D. ${ }^{3}$, Ni Komang Ekawati ${ }^{4}$

\begin{abstract}
According to UNODC (The United Nations Office on Drugs and Crime) in the World Drug Report in 2015, the estimated drug users in 2013 were 246 million people, where the highest number of drug cases occurred in the population of 15-64 years of age. The biggest factor that can influence the success of drug users to leave drugs forever is the strong intentions from within and positive family support. This study aimed to find out in depth regarding the process of establishing family support for rehabilitated adolescent drug abusers at Bangli Mental Hospital. This study employed a qualitative design. The qualitative data were gathered through in-depth interview to 12 informants, where 6 informants were the parents of the drug abusers, 3 nurses in the rehabilitation room, and 3 adolescents who were being rehabilitated in Bangli mental hospital. This study revealed that the family had internal and external factors as well as inhibiting factors in forming and providing support to residents. In forming support, the residents' family had internal and external factors that influenced it, moreover they also had inhibiting factors such as feeling of weary and distance from home.
\end{abstract}

Index Terms - support, family, adolescents, rehabilitation

\section{INTRODUCTION}

According to UNODC (The United Nations Office on Drugs and Crime) in its World Drug Report in 2015, the estimated drug users in 2013 were 246 million people, where the highest number of drug cases occurred in the population of 15-64 years of age. The results of the projection of the prevalence of drug abuse in Indonesia in 2014 were around four million, which was equivalent to $2.2 \%$ of the population ranging from 10-59 years of age, or $184,175,000$ people[1]. In the same year, Bali was ranked eighth for drug abuse cases with 66,785 people, or equal to $2.2 \%$ of the population ranging from 10-59 years of age, or $3,008,900$ people[2]. The high incidence of drug use by adolescents is not followed by support from their family and community, although family support is very influential on the low incidence of relapse[3]. This study aimed to find out in depth regarding the process of establishing family support for rehabilitated adolescent drug abusers at Bangli Mental Hospital. This research is expected to contribute positively to several areas. First, this research is expected to increase the knowledge about the process of forming family support for adolescent drug abusers who are being rehabilitated. Secondly, this research could be used as a basis for drug abuser rehabilitation planning in Bangli 
Mental Hospital, as well as becoming a guideline or governance to medical staffs who are taking care of drug rehabilitation patients. Family support is the attitude, actions and acceptance of the family of its members. Family members are seen as an inseparable part of the family environment 4 . Motivation is everything that drives someone to do something [5]. The biggest factor that can influence the success of drug users to leave drugs forever is the strong intentions from within and positive family support [6]. Selfesteem formation among people who are in rehabilitation for drug abuse depends on various factors such as family support, peer support, life experience, skills and traits, spirituality, policies, parenting history, physical and social environments[7].

\section{METHOD}

This present study employed qualitative design. This approach was chosen in order to explore the role of the family in providing support to drug abusers more deeply hospital. A qualitative study was conducted between April and June 2019. Furthermore, the subjects of this study were families, including both parents and closest relatives who provide support to the rehabilitated drug abusers at Bangli mental.This study dug a deep information from 12 informants consisted of 6 parents from the adolescents' drug abusers who were under rehabilitation, 3 nurses from rehabilitation room, and 3 rehabilitated drug abusers in Bangli mental hospital. Inclusion criteria included parents or families who have teenagers are being rehabilitated in Darmawangsa Ward Bangli Mental Health Hospital for at least two weeks and agreed to participate in the study. while the exclusion criteria from this study are parents who are not willing to be interviewed. Data were collected through in-depth interview directly by the principal investigator where audio-recorded and transcribed using verbatim approach conducted.

\section{METHOD}

This present study employed qualitative design. This approach was chosen in order to explore the role of the family in providing support to drug abusers more deeply hospital. A qualitative study was conducted between April and June 2019. Furthermore, the subjects of this study were families, including both parents and closest

\section{RESULt}

Demographic data of respondents in this study are the age of parents or family in the range of 35-59 years, and the age of adolescents in the range of 18-21 years. Some parents or families come from districts far from Bangli Mental Hospital, for example Singaraja Regency, Denpasar City, and Badung Regency. In the process of establishing family support, there are two important factors, namely internal and external factors. On the other hand, inhibiting factor also needs to be considered.

\section{A. Internal Factor}

The internal factor that influenced informants to form support covers sex, physical condition, knowledge, experience, spiritual education from the medical staffs. All these are quoted as follows.

"Of course I felt down, I was very shock to hear that my son experiences this condition, but my husband braced me up, perhaps it was influenced by the fact that he is a man, he gave more support than ever to me and my son..." $\mathrm{IN}-1$, 56 years old.

"mm... yes.. I try to be tough, who else if it's not me. His father is still ill, that forces me to handle this with his brothers..." IN-4, 35 years old.

"I was trying not to cry, I read a lot regarding this case, there were his friends as well who told us similar stories. I firmly believe that as parents, particularly me as father, we need to be tough. This also for his sake to get better from his condition..." IN-5, 58 years old.

"Of course we were sad when we knew this. However, from what I heard from those who have been rehabilitated here, I realized that our role and support was very important, ... 'IN-6, 48 years old.

"My strength comes from prayer. I always feel sad and sorrow whenever I remember this, but when it came, I took my incense and pray..." IN-3, 59 years old.

\section{B. ExternalFactor}

The external factors that are believed to form better support for the rehabilitated drug abusers covers the medical staffs, hospital policy, and social environment. Here are some quotations from the informants that the researcher had gathered

"I am getting stronger ever since that I was informed about my son's progress from the nurse and doctors. Overall, it is very useful for me...." IN-3, 59 years old.

"I am very thankful because the staffs of this hospital give me permission to look after my kid twice a week and give him support and completely healthy...” IN-2, 45 years old.

"Our neighbors help me a lot to put our condition this way. At the beginning I was down because I am very shy that the neighbors knew our son's condition. Unexpectedly, they gave us endless support and make me stronger..." IN1,56 years old.

\section{Inhibiting Factor}

This factor is also known as obstacles in establishing the family support to the rehabilitated drug abusers. These factors are the feeling of weary from the family members because the residents keep doing physical abuse, and the other one is the distance from home to the hospital.

"I feel tired and whacked hearing him shouting over and over. He even hit me..." IN-2, 45 years old.

"I think from the family point of view, they already have had enough and that makes them feel that it is better to leave the resident here." Nurse 1 
"I am not going to the hospital every day, my house is in Singaraja, so yeah, perhaps once in a month" IN-3, 59 years old.

On the other hand, residents lie their hope to their family to support them to completely rehabilitated

" The support from my family means so much for me, their presence here makes me feel that I belong to them in joys and perish" Res-5, 21 years old

\section{DISCUSSION}

Family is the most important factor that increases the spirit of drug abusers. Family support is very much expected by the residents while they are in rehabilitation6. The process of esthabilising family support for adolescents who are being rehabilitated consists of internal and external factors. Physiological and psychological aspects are the two most influential internal factors for the parents or families, while socio and non-socio environmental aspects are two that works for the external factor7. This research is correlate with the precede and procede theory, one of the factors that determine behavior is predisposing factor, where it covers individual knowledge, attitude trust, tradition, social norms, and principles that lie within the society8. In short, the predisposition factors found in this study are knowledge, experience, sex, spiritualism, and physical condition. The limitation of this study is the lack of available informants, so the information obtained by researchers feels that it is still very limited

\section{CONCLUSION}

In order to establish supports for residents, family is influenced by internal and external factors as well as inhibiting factors such as feeling of weary, and the distance from home to the hospital.

\section{REFERENCES}

[1] Badan Narkotika Nasional, "Data Kasus Narkoba", BNNP Bali, 2016.

[2] Badan Narkotika Nasional, "Survei Nasional Perkembangan Penyalahguna Narkoba”, Lap Survei, 2014.

[3] Sariyani M.D., Ekawati N.K., Duarsa D.P., et al., "Self-esteem formation among people who are in rehabilitation for drug abuse in Bangli Mental Health Hospital ,Bali ,Indonesia.”, Intisari Sains Medis, 2019.

[4] Bell R.A., Suerken C.K., et. al., "CAM Use Among Older Adults Age 65 Or Older With Hypertension In The United States: General Use And Disease Treatment.", J Altern Complement Med, 2006.

[5] Nursalam, "Manajemen Keperawatan. Indonesia: Salemba Medika", 2013.

[6] Buckner J.C., Mandel W., "Risk Faktors for Depressive Symptomatology in a Drug Using Population. Amerika.", 1990. [Online]Available:http://ajph.aphapublications.org/doi/abs/10.2105/ AJPH.80.5.580 (1990).

[7] Ariyani A., "Perbedaan Hope dan Self esteem antara Remaja yang Pernah Menggunakan Narkoba dan Remaja yang tidak Menggunakan Narkoba.”, 2004. [Online].Available: http://lib.ui.ac.id/bo/uibo/detail.jsp?id=20344351\&lokasi=lokal (2004).

[8] Aztri S., Milla M., "Rasa Berharga dan Pembelajaran Hidup Mencegah Kekambuhan Kembali pada Pecandu Narkoba Studi Kualitatif Fenomenologis. Psikologi; IX.”. 